\title{
Effect of milking frequency and nutritional level on aspects of the health and welfare of dairy cows
}

\author{
D. E. Gleeson ${ }^{1 \dagger}$, B. O’Brien ${ }^{1}$, L. Boyle ${ }^{1}$ and B. Earley ${ }^{2}$ \\ ${ }^{1}$ Teagasc, Moorepark Dairy Research Centre, Fermoy, Co. Cork, Ireland; ${ }^{2}$ Teagasc, Grange Beef Research Centre, Dunsany, Co. Meath, Ireland
}

(Received 5 January 2006; Accepted 6 November 2006)

The objective of this experiment was to investigate the effect of milking frequency and nutritional level on some aspects of animal
health. Holstein-Friesian cows $(n=60)$ were assigned post calving to a factorial arrangement of treatments; twice a day (TAD)
milking on a high or low nutritional level; once a day $(O A D)$ milking on a high or low nutritional level. Milking characteristics
were recorded daily. Blood samples to evaluate changes in the composition of the blood cells, milk leakage, udder tension and
locomotory ability were measured on four occasions. Teat-ends were classified for hyperkeratosis (HK) monthly post partum. TAD
had longer daily milking times $(P<0.001)$ compared with OAD cows. There was no effect of milking frequency or nutritional
level on morning milking time, time to milk letdown or peak milk flow rate $(P>0.05)$. High nutritional level cows had higher
average flow-rates $(P<0.05)$ than low nutritional level cows. Neither milking frequency nor nutritional level affected HK
$(P>0.05)$. However, HK values were positively correlated with daily milking time for OAD cows for 6 months of lactation
$(P<0.05)$. This correlation was significant $(P<0.01)$ for cows milked OAD on high nutrition during the peak lactation period.
$O A D$ cows had higher levels of milk leakage compared with TAD cows during the month of May ( $P<0.01)$. Cows on high
nutrition milked OAD showed higher udder firmness scores than cows milked once or twice daily at the low nutrition level in June
and July $(P<0.05)$. OAD cows had higher locomotion scores compared with TAD cows ( $P<0.001)$. Locomotion and udder
firmness scores were significantly correlated for OAD in June $(P<0.05)$. OAD cows had lower blood lymphocyte counts,
numerically higher counts of neutrophil and a higher monocyte count at peak lactation compared with TAD cows suggesting that
OAD cows had altered immune responses. The increase in milk leakage, higher udder firmness and locomotion scores in
conjunction with changes in blood cells, suggests that OAD milking may have caused some discomfort to the cows during peak
lactation. A reduction in the concentrate input to OAD cows during this period could ameliorate this problem.

Keywords: animal welfare, dairy cows, milking interval, milking rate, teats

\section{Introduction}

Milking dairy cows once compared with twice daily results in a loss of milk production, but has a positive effect on body condition score (Davis et al., 1999; Rémond et al., 2002; O'Brien et al., 2005). However reduced milking frequency may result in increased milk leakage, longer milking times and udder distension. Some of these factors in turn could impact on animal health and welfare by affecting cow locomotory ability and udder health.

Milk leakage is a condition in which milk loss occurs through the teat canal. Milking high yielding dairy cows once per day could increase the degree of udder filling prior to milking, resulting in larger volumes of milk being stored

\footnotetext{
${ }^{\dagger}$ E-mail: david.gleeson@teagasc.ie
}

in the teat cistern. This could increase pressure on the teat sphincter before milking, thus resulting in milk leakage. The frequency of milk leakage differs between farms and can range from 0 to $36 \%$ within a farm (Schukken et al., 1991). For cows that are housed during lactation, leaked milk enhances bacterial growth in the bedding material and thus increases the risk of environmental mastitis (Elbers et al., 1998; Waage et al., 2001). However, the health implications of milk leakage for cows at pasture are less well known. Automatic milking systems appear to increase the risk of milk leakage possibly due to irregular milking intervals (Persson Waller et al., 2003). An association between peak milk flow-rate and milk leakage was also observed in automatic milking systems (Persson Waller et al., 2003). Milk yield per cow can influence cow peak milk flow-rate 
(Blake and McDaniel, 1978). Irregular milking intervals might influence milk yield per milking and in turn, peak milk flow rate and the level of milk leakage. Klass et al. (2005) concluded that higher yielding cows, easy milking cows and cows with high peak milk flow-rates were more likely to have an increased risk of milk leakage. Therefore, differences in milk yield per cow due to milking frequency or cow nutritional level may influence peak milk flow-rates and as a consequence milk leakage. A linear association was detected between days in milk and the risk of milk leakage with cows $<100$ days calved more likely to have milk leakage (Klass et al., 2005). Bruckmaier and Hilger (2001) also suggested that milk leakage decreased as days in milk increased. Therefore, the stage of lactation is important if differences in milk leakage are to be observed.

Once daily milking could have potential benefits in terms of improved hoof health due to reduced daily walking time on farm roadways (Boyle et al., 2005). However, reducing milking frequency is likely to increase cow discomfort due to udder distension (Osterman and Redbo, 2000). Discomfort due to an increase in udder size may act as an impediment to comfortable movement of the rear legs. Indeed Boelling and Pollott (1998) suggested that poor locomotion could be a problem for cows with a large udder. Furthermore, udder firmness may be high in cows milked less frequently, especially in early lactation, and this could also influence cow locomotory ability. A high nutritional level during early lactation could further aggravate the problem (Manson and Leaver, 1988).

Teat hyperkeratosis (HK) or teat callosity is a commonly observed teat condition in dairy cows and describes a thickened smooth keratin ring or extending fronds of keratin around the teat orifice (Sieber, 1980; Shearn and Hillerton, 1996; Neijenhuis et al., 2000). Michel et al. (1974) observed HK with suckler cows and Sieber (1980) reported HK with hand milked cows. The condition is the result of a normal physiological process of adaptation to milking which continues during lactation (Sieber and Farnsworth, 1981). The level of teat HK can be directly related to specific conditions in the milking machine. For example, the length of time teats are exposed to a vacuum may affect the level of HK (Hamann, 1987). Shearn and Hillerton (1996) concluded that higher yielding cows have higher HK scores and that this may be due to longer milking times. Likewise, Mein and Thompson (1993) suggested that the degree of HK was greater with increasing milk yield or machine-on time. Teat $\mathrm{HK}$ is also lower where clusters were removed at a flowrate of $0.8 \mathrm{~kg} / \mathrm{min}$ compared with a cluster removal time of $0.2 \mathrm{~kg} / \mathrm{min}$ (Gleeson et al., 2003). Hence, the condition of the teats of cows milked once per day may be improved due to fewer milking occasions. On the other hand, a longer duration of milking on one occasion per day could negatively affect teat condition. Milking frequency and nutritional level could influence milking characteristics such as cluster-on time due to the larger milk volume at one milking. Physiological or patho-physiological responses of the body to stress due to factors such as udder tension and restricted locomotory ability may be reflected in changes in blood composition. Blood cell constituents maintain a physiological balance between environmental conditions and an animal's body by restoring normal homeostasis (Radostits et al., 1994). Neutrophilia and lymphopenia is a common finding in stressed animals and is associated with changes in white blood cell trafficking and release from the bone marrow by elevated concentrations of glucocorticoids (Dunn, 1989).

The objective of this study was to investigate the effect of milking frequency and nutritional level on some aspects of health of cows as measured by long-term (teat condition, milking characteristics over a complete lactation) and short-term (incidence of milk leakage, udder firmness, locomotory ability and blood cell composition in early lactation) indicators.

\section{Material and methods}

\section{Animals and experimental design}

Sixty spring-calving, pluriparous Holstein-Friesian cows were blocked according to expected calving date, parity and previous lactation milk yield. Cows were assigned to a factorial arrangement of treatments after calving; twice a day (TAD) milking on a high or low nutritional level; once a day (OAD) milking on a high or low nutritional level. High nutritional level and low nutritional level were defined by total concentrate offered over the complete lactation (420 kg and $137 \mathrm{~kg}$ per cow, respectively) and postgrazing sward height (75 and $55 \mathrm{~mm})$, respectively, during the grazing season. Mean calving date was 11 March. Cows were housed in cubicles until turnout to pasture on the 22 March. During the indoor period all cows received ad libitum silage and a concentrate supplementation $(7 \mathrm{~kg}$ per cow per day and $4 \mathrm{~kg}$ per cow per day, to high and low nutritional groups, respectively). At turnout, concentrate supplementation was reduced to $4 \mathrm{~kg}$ per cow per day and $1 \mathrm{~kg}$ per cow per day for high and low nutritional groups, respectively. Cows grazed a similar ryegrass pasture on adjacent paddocks, without supplementation from 17 April until 9 October. Pasture allowance during the grazing period was $28 \mathrm{~kg}$ per cow per day and $18 \mathrm{~kg}$ per cow per day for high and low nutritional groups, respectively. Pasture allowance was dictated by paddock size and pre-grazing height. During the late grazing period (21 October-30 November) cows were supplemented with silage and concentrate $(4 \mathrm{~kg}$ per cow per day and $2 \mathrm{~kg}$ per cow per day for high and low nutritional groups, respectively). Cows were milked as one group in a 20-unit, 80degree side-by-side milking parlour, using $16 \mathrm{~mm}$ (internal diameter) long milk tubes, with a milk lift of $1.5 \mathrm{~m}$ above the cow standing to a $72 \mathrm{~mm}$ (internal diameter) single milk-line. Pre-milking teat preparation consisted of washing with warm running water and drying with individual paper towels. The milking unit consisted of a heavy cluster weight $(3.2 \mathrm{~kg})$ with a claw volume of $150 \mathrm{ml}$, wide-bore tapered liners $(31.6-21.0 \mathrm{~mm})$ and a simultaneous pulsation 
pattern. Clusters were automatically removed as directed by electronic milk meters linked to a software program, when milk flow-rate dropped to $0.2 \mathrm{~kg} / \mathrm{min}$ with a delay time of $20 \mathrm{~s}$. OAD cows were milked at $0730 \mathrm{~h}$ and TAD cows were milked at 0730 and $1530 \mathrm{~h}$.

\section{Milking characteristics}

Milking characteristics including milk letdown time (s), cluster-on time (s), peak milk flow-rate $(\mathrm{kg} / \mathrm{min})$, and average flow-rate were recorded daily for each individual cow using Dairymaster Weigh-all electronic milk meters (Dairymaster, Causeway, Co Kerry, Ireland). Milk letdown time was computed as the time interval from cluster application to when the milk flow increased to $0.2 \mathrm{~kg} / \mathrm{min}$. Milking time was computed as the time interval from milk let down to automatic cluster removal when flow-rate decreased to $0.2 \mathrm{~kg} / \mathrm{min}$. Data for each individual cow were averaged for each month of lactation.

\section{Teat hyperkeratosis}

Teat orifices were classified for hyperkeratosis (HK) using a severity scale described by Neijenhuis (1998). Teats were scored and placed into one of five classes. Score 1 was a normal teat-end orifice. Score 2 was a slight smooth or broken ring of keratin while score 3 was a moderate raised smooth or broken ring of keratin. Score 4 indicated a large raised smooth or broken ring of keratin, while score 5 indicated a severe broken ring of keratin. Teat inspections were always conducted by the same observer and were carried out within three days of calving and monthly thereafter until the end of lactation. The operator, using a lamp to illuminate the teat-ends, classified teats for HK immediately after cluster removal at the morning milking. A total HK score for each cow on each inspection was obtained by calculating the average score of the four teats.

\section{Milk leakage and udder firmness}

One operator inspected cows for milk leakage and udder firmness on two consecutive mornings in mid April, May, June and July. Observations were carried out when cows were presented for milking in the milking stalls and before teat preparation. The intramammary pressure was assumed to be greatest at this time. Cows were scored as being positive (i.e. leakage of milk from one or more teats) or negative for milk leakage each day. Where cows were positive one morning and negative the following morning, or vice versa, they were classified as being positive overall. The firmness of the udder was assessed by manually palpating the udder between the cows' hind legs and categorizing it according to a 3-point scoring system. Score $1=$ soft, udder yields significantly to gentle pressure from the fingers; score $2=$ firm, udder yields slightly to gentle pressure from the finger tips; score $3=$ hard, the udder tissue does not yield to gentle pressure from the finger tips. The average score of the two consecutive days per month was used in the statistical analysis.

\section{Locomotion}

Cow locomotory ability was observed on two consecutive mornings in mid April, May, June and July. All cows in each treatment were herded to the paddock entrance prior to the morning milking. Cows were allowed to leave the paddock singly and were observed walking past and then away from the observer on the farm roadway. A sound cow walks with a level spine (1. spine curvature). The hind feet almost exactly trace the placement of the fore feet (2. tracking). The gait appears comfortable and the cow walks at an even pace (3. speed) with little movement of the head (4. head carriage). The feet point in the direction of travel (5. abduction/adduction). Overall locomotory ability and the five individual aspects of locomotion detailed above were scored using a modification of a five-point scale developed by O'Callaghan et al. (2003) (Table 1). The average locomotion score for the two consecutive days per month was used in the statistical analysis. One observer who was unfamiliar with the milking treatment or nutritional level conducted all locomotion scoring.

\section{Haematological parameters}

Unclotted (EDTA) whole blood samples were collected from 40 cows ( 10 cows per treatment) 52 days after the mean calving date. Samples were collected at four additional sampling dates at 21-day intervals. Blood samples were analysed for total white blood cells (WBC), red blood cells (RBC), monocyte and lymphocyte numbers, mean corpuscular volume (MCV), haemoglobin ( $\mathrm{Hb})$, and platelet numbers using an automated electronic particle analyser (Celltac, MEK-6108K, Nihon-Kohdon, Tokyo, Japan) within $6 \mathrm{~h}$ of blood sampling. Thin blood smears on grease free glass slides (Gold star micro slides, Chance Propper Ltd, UK) were prepared for WBC differential population count. The smears were air-dried and stained using the haematology three-step stain for differentiation of morphological cell types (Accralab, Fisher Scientific Company, L.L.C., 8365 Valley Pike, Middleton, VA 22 645-0307, USA). One hundred cells, including neutrophils, band neutrophils, basophils, eosinophils, monocytes and lymphocytes were counted under the microscope at $40 \times$.

\section{Statistical analysis}

All data were analysed using SAS software (SAS Institute Inc., 1989). All variables were first tested for normality (UNIVARIATE procedure). Variables associated with milking characteristics, locomotion scores, WBC differential counts and haematological parameters were analysed using general linear mixed models (MIXED procedure) with time as a repeated measure. Degrees of freedom were estimated using Satterthwaite's formula (Littell et al., 1996). The model included effects for milking frequency, nutritional level, time, block and all two- and three-way interactions. The cow effect was considered random and the other effects were considered fixed in all models. The model was reduced if interactions were not significant $(P>0.05)$. Means comparisons were made based on differences in 
Gleeson, O'Brien, Boyle and Earley

Table 1 Locomotion scoring system

\begin{tabular}{|c|c|c|}
\hline Aspect of locomotion & Score & Definition \\
\hline \multirow[t]{5}{*}{ Spine curvature } & 1 & Spine flat during locomotion \\
\hline & 2 & $\begin{array}{l}\text { Slight departure from the horizontal plane, only } \\
\text { obvious intermittently as cows walks }\end{array}$ \\
\hline & 3 & Slight departure from horizontal but constant \\
\hline & 4 & Spine obviously curved \\
\hline & 5 & Spine fully arched \\
\hline \multirow[t]{5}{*}{ Speed } & 1 & Normal locomotion at a comfortable pace \\
\hline & 2 & Locomotion slower than normal \\
\hline & 3 & Slow, slightly hesitant walk and/or slight reluctance to bear weight \\
\hline & 4 & Very slow, hesitant walk and/or reluctance to bear weight \\
\hline & 5 & Cow unwilling/unable to walk \\
\hline \multirow[t]{5}{*}{ Tracking } & 1 & Hind footprint fully traces, or is more forward than front footprint \\
\hline & 2 & Hind footprint partly traces (slightly behind) front footprint \\
\hline & 3 & Toe of hind footprint reaches heel of front footprint \\
\hline & 4 & Hind footprint approx. $30 \mathrm{~cm}$ behind front footprint \\
\hline & 5 & Hind footprint more than $30 \mathrm{~cm}$ 'behind' front footprint \\
\hline \multirow[t]{5}{*}{ Head carriage } & 1 & Normal vertical movement during locomotion \\
\hline & 2 & Head 'nods' slightly during locomotion \\
\hline & 3 & Marked vertical head movement during locomotion \\
\hline & 4 & Severe vertical movement during locomotion \\
\hline & 5 & Head lowered almost to ground level with each step \\
\hline \multirow[t]{5}{*}{ Abduction/adduction } & 1 & Hind limbs move forward parallel to vertical mid line of animal \\
\hline & 2 & Slight deviation from mid line of animal \\
\hline & 3 & Hooves form a $\mathrm{C}$ shape in the air as they move forward \\
\hline & 4 & C shape so defined as to be almost circular \\
\hline & 5 & Hooves circle completely in the air between each step \\
\hline
\end{tabular}

least squares means, with $P$ values adjusted for multiple comparisons using the Tukey option in the MIXED procedure. Results are expressed as least-squares means and standard errors of the mean (s.e.). HK and udder tension scores were analysed by the Kruskal and Wallis test using the NPARIWAY procedure. Data on numbers of cows in each treatment that were positive for milk leakage were analysed by the $\chi^{2}$ tests using the FREQ procedure. The correlation between daily milking time and $\mathrm{HK}$ scores on each month of lactation and between locomotion and udder tension scores at the four inspections was carried out by non-parametric Spearman rank order correlations using the CORR procedure.

\section{Results}

\section{Milking characteristics}

Total 305-day milk production was lower for OAD milking $(4620 \mathrm{~kg})$ than TAD milking (6214) and for low nutritional level $(4924 \mathrm{~kg})$ than high nutritional level $(5910 \mathrm{~kg})$ (O'Brien et al., 2006). There were no significant interactions between milking frequency and nutritional level for any of the milking characteristics variables $(P>0.10)$. Thus effects of the two factors are presented separately. Milking frequency had a significant effect on daily milking time $\left(F_{1,62.3}=125.95 ; P<0.001\right)$ (Table 2 ). There was no effect of nutritional level on daily milking time $\left(F_{1,62.3}=1.96 ; P>0.10\right)$. Furthermore, there was no effect of milking frequency or nutritional level on morning milking time $\left(F_{1,64}=1.63\right.$ and $F_{1,60.5}=2.20 ; P>0.10$ respectively), time to milk let-down $\left(F_{1,58.3}=0.90\right.$ and $\mathrm{F}_{1,58.3}=2.26 ; P>0.10$ respectively) or peak milk flow rate $\left(F_{1,63.7}=0.14\right.$ and $F_{1,59.9}=1.90 ;(P>0.10)$ (Table 2). Milking frequency had no effect on average milk flow rate $\left(F_{1,73.1}=1.42 ; P>0.10\right)$. However, average milk flow rate was higher at the high nutritional level $\left(\mathrm{F}_{1,71.4}=4.80\right.$; $P<0.05)$. There was a significant effect of stage of lactation for all variables $(P<0.001)$. The interaction between stage of lactation and milking frequency was significant for morning milking time, peak and average milk flow rate

Table 2 Effect of milking frequency (once or twice) and nutritional level (high or low) on daily milking time and milking characteristics at the morning milking

\begin{tabular}{|c|c|c|c|c|c|}
\hline & \multicolumn{2}{|c|}{$\begin{array}{l}\text { Milking } \\
\text { frequency }\end{array}$} & \multicolumn{2}{|c|}{$\begin{array}{l}\text { Nutritional } \\
\text { level }\end{array}$} & \multirow[b]{2}{*}{ s.e. } \\
\hline & Twice & Once & High & Low & \\
\hline Daily milking time (s) & $692^{\mathrm{a}}$ & $414^{b}$ & 570 & 536 & 17.88 \\
\hline \multicolumn{6}{|l|}{ Morning milking } \\
\hline Milking time (s) & 386 & $414<$ & 416 & 384 & 15.50 \\
\hline Time to let-down (s) & 0.37 & $7 \quad 0.35$ & 0.35 & 0.37 & 0.010 \\
\hline Peak milk flow rate $(1 / \mathrm{min})$ & 4.36 & 4.45 & 4.56 & 4.24 & 0.168 \\
\hline Average milk flow rate (l/min) & 2.45 & 2.58 & $2.63^{c}$ & $2.41^{\mathrm{d}}$ & 0.075 \\
\hline
\end{tabular}


$(P<0.01)$. However, when the $P$ values were adjusted for multiple comparisons using Tukey, there were no meaningful differences between treatments on different months of lactation $(P>0.10)$.

\section{Teat hyperkeratosis}

There was no effect of milking frequency or nutritional level on HK scores $(P>0.10)$. The mean lactation HK score was $11.2( \pm 0.49)$ and $10.2( \pm 0.55)$ for twice and once daily milked cows, respectively, and was 10.8 $( \pm 0.55)$ and $10.5( \pm 0.41)$ for high and low nutrition cows, respectively. However, OAD cows tended to have lower scores than TAD cows in May $(9.9 \pm 0.52 \mathrm{v}$. $11.5 \pm 0.59 ; P=0.068)$ and they had numerically lower scores for all other months (Table 3). Teat HK scores increased in both milking frequency treatments during the first 5 months of lactation $(P<0.001)$.

HK scores of OAD cows were positively and significantly correlated with daily milking time from April to September $(P<0.05)$ (Table 3). There was no correlation between HK scores of TAD cows and daily milking time $(P>0.10)$. There was a positive correlation between HK scores and daily milking time for cows milked once daily on high nutrition during the months of April, May, June and July $(P<0.05)$ (Table 4). There was no correlation between HK scores in cows milked once daily on low nutrition and daily milking time $(P>0.10)$.

\section{Milk leakage and udder firmness}

The percentage of cows that were recorded positive for milk leakage on at least one inspection day was 17 and $28 \%$ for $T A D$ and $O A D$ cows, respectively. Significantly more OAD cows were positive for milk leakage prior to the morning milking in May $(P<0.01)$ (Table 5). There was no effect of nutritional level on milk leakage $(P>0.10)$.

Table 3 Effect of milking frequency (once or twice) on the correlation between daily milking time and teat hyperkeratosis (HK) score in each month of lactation

\begin{tabular}{|c|c|c|c|c|c|c|c|c|}
\hline \multirow[b]{3}{*}{ Month } & \multicolumn{8}{|c|}{ Milking frequency } \\
\hline & \multicolumn{4}{|c|}{ Once } & \multicolumn{4}{|c|}{ Twice } \\
\hline & $\begin{array}{l}\text { Milking } \\
\text { time (s) }\end{array}$ & $\begin{array}{c}\text { HK } \\
\text { score }\end{array}$ & $r$ & $P$ & $\begin{array}{l}\text { Milking } \\
\text { time (s) }\end{array}$ & $\begin{array}{c}\text { HK } \\
\text { score }\end{array}$ & $r$ & $P$ \\
\hline March & 459 & 8.2 & 0.34 & NS & 750 & 8.9 & -0.02 & NS \\
\hline April & 475 & 9.7 & 0.52 & $* *$ & 764 & 10.8 & 0.25 & NS \\
\hline May & 473 & 9.9 & 0.45 & $* *$ & 760 & 11.5 & 0.25 & NS \\
\hline June & 435 & 10.8 & 0.51 & $* *$ & 709 & 11.6 & 0.11 & NS \\
\hline July & 413 & 11.1 & 0.49 & $* *$ & 677 & 11.9 & -0.02 & NS \\
\hline August & 388 & 10.9 & 0.32 & * & 650 & 11.9 & 0.24 & NS \\
\hline September & 371 & 10.5 & 0.46 & * & 642 & 11.7 & 0.07 & NS \\
\hline October & 345 & 10.6 & 0.32 & NS & 639 & 11.4 & 0.50 & NS \\
\hline November & 326 & 8.3 & 0.13 & NS & 599 & 10.5 & 0.48 & NS \\
\hline
\end{tabular}

NS $=$ not significant; ${ }^{*} P<0.05 ;{ }^{*} P<0.01$.
Table 4 Effect of nutritional level (high or low) on the correlation between daily milking time and teat hyperkeratosis (HK) for cows milked once a day on each month of lactation

\begin{tabular}{|c|c|c|c|c|c|c|c|c|}
\hline \multirow[b]{3}{*}{ Month } & \multicolumn{8}{|c|}{ Nutritional level } \\
\hline & \multicolumn{4}{|c|}{ High } & \multicolumn{4}{|c|}{ Low } \\
\hline & $\begin{array}{l}\text { Milking } \\
\text { time (s) }\end{array}$ & $\begin{array}{c}\text { HK } \\
\text { score }\end{array}$ & $r$ & $P$ & $\begin{array}{l}\text { Milking } \\
\text { time (s) }\end{array}$ & $\begin{array}{c}\text { HK } \\
\text { score }\end{array}$ & $r$ & $P$ \\
\hline March & 488.0 & 8.1 & 0.39 & NS & 429.0 & 8.3 & 0.16 & NS \\
\hline April & 504.1 & 9.6 & 0.76 & $* *$ & 446.6 & 9.8 & 0.17 & NS \\
\hline May & 497.6 & 9.7 & 0.56 & * & 448.1 & 10.1 & 0.31 & NS \\
\hline June & 454.8 & 10.6 & 0.67 & $* *$ & 414.5 & 10.9 & 0.31 & NS \\
\hline July & 438.6 & 10.9 & 0.66 & $* *$ & 383.9 & 11.4 & 0.38 & NS \\
\hline August & 409.4 & 11.2 & 0.36 & NS & 365.1 & 10.7 & 0.21 & NS \\
\hline September & 391.6 & 11.1 & 0.43 & NS & 348.5 & 9.9 & 0.26 & NS \\
\hline October & 363.7 & 10.7 & 0.22 & NS & 325.6 & 10.5 & 0.46 & NS \\
\hline November & 340.0 & 9.7 & 0.56 & NS & 312.6 & 7.3 & -0.21 & NS \\
\hline
\end{tabular}

NS $=$ not significant; ${ }^{*} P<0.05 ;{ }^{*} P<0.01$.

There was no effect of milking frequency on udder firmness scores $(P>0.10$, data not shown). However, nutritional level had a significant effect on udder firmness scores with high nutrition cows having higher scores in June and July $(P<0.05$, data not shown). Furthermore, there was an interactive effect of milking frequency and nutritional level on udder firmness scores (Table 6). Cows milked once daily on high nutrition had significantly higher udder tension scores than cows milked once or twice daily on low nutrition and cows milked twice daily on high nutrition levels in June $(P<0.01)$ and than cows milked once or twice daily at a low nutrition level in July $(P<0.05$; Table 6).

\section{Locomotion}

There was a significant effect of milking frequency (OAD: 8.25 v. TAD: 7.43 , s.e. $=0.152 ; F_{1,44}=14.4 ; P<0.001$ ) on locomotion scores. Nutritional level had no effect on locomotion scores $\left(F_{1,46.4}=1.43 ; P>0.10\right)$. Furthermore, there was a significant interaction between milking frequency and inspection date on locomotion scores $\left(F_{3,145}=73.9 ; P<0.001\right)$ (Table 7). OAD milking resulted in significantly higher locomotion scores than TAD in April $(P<0.001)$ and numerically higher scores in both May

Table 5 Effect of milking frequency (once or twice) and nutritional level (high or low) on proportion of cows (\%) (number affected/number inspected) leaking milk at four sampling dates

\begin{tabular}{|c|c|c|c|c|}
\hline \multirow[b]{2}{*}{ Sample date } & \multicolumn{2}{|c|}{ Milking frequency } & \multicolumn{2}{|c|}{ Nutritional level } \\
\hline & Twice & Once & High & Low \\
\hline 21 April & $23(7 / 30)$ & $43(13 / 30)$ & $33(10 / 30)$ & $33(10 / 30)$ \\
\hline 20 May & $17(5 / 30)^{a}$ & $53(16 / 30)^{b}$ & $30(9 / 30)$ & $40(12 / 30)$ \\
\hline 17 June & $24(7 / 29)$ & $30(9 / 30)$ & $23(7 / 30)$ & $31(9 / 29)$ \\
\hline 18 July & $7(2 / 30)$ & $23(7 / 30)$ & $17(5 / 30)$ & $13(4 / 30)$ \\
\hline
\end{tabular}

\footnotetext{
${ }^{a, b}$ Values within rows with different superscripts are different $(P<0.01)$.
} 
Gleeson, O'Brien, Boyle and Earley

Table 6 Interactive effects of milking frequency (once or twice) and nutritional level (high or low) on udder firmness scores (mean \pm s.e.) at four sampling dates

\begin{tabular}{lcccc}
\hline \hline Sample date & Once-high & Once-low & Twice-high & Twice-low \\
\hline 21 April & $2.17 \pm 0.093$ & $1.83 \pm 0.093$ & $2.03 \pm 0.077$ & $2.07 \pm 0.067$ \\
20 May & $2.07 \pm 0.083$ & $1.80 \pm 0.082$ & $1.87 \pm 0.059$ & $1.77 \pm 0.096$ \\
17 June & $2.07 \pm 0.045^{\mathrm{a}}$ & $1.60 \pm 0.111^{\mathrm{b}}$ & $1.63 \pm 0.114^{\mathrm{b}}$ & $1.71 \pm 0.101^{\mathrm{b}}$ \\
18 July & $2.00 \pm 0.154^{\mathrm{c}}$ & $1.47 \pm 0.13^{\mathrm{d}}$ & $1.67 \pm 0.105^{\mathrm{c}, \mathrm{d}}$ & $1.50 \pm 0.120^{\mathrm{d}}$ \\
\hline \hline
\end{tabular}

$a, b, c, d$ Values within rows with different superscripts are different $(P<0.01$ and $P<0.05$, respectively).

and July. There was a significant correlation between locomotion and udder firmness scores of OAD cows at the June inspection $(P<0.05)$. Furthermore, the correlations tended to be significant in April and May $(P<0.10)$. There was no correlation between locomotion and udder firmness scores of TAD cows $(P>0.10)$.

\section{Haematological parameters}

There was no effect of milking frequency or nutritional level on WBC or RBC counts or PCT (haematocrit) parameters $(P>0.10)$ (Table 8$)$. However, there was a significant effect of milking frequency on $\mathrm{Hb}$ values $\left(F_{1,41.3}=6.11, \quad P<0.05\right.$, Table 8). The interaction between milking frequency and nutritional level tended to be significant for WBC $\left(F_{1,58.5}=3.61, P=0.063\right)$ with TAD at low nutrition having lower values than animals in the other three treatments $(6.41$ v. 7.47 [OAD at high nutrition], 7.54 [OAD at low nutrition] and 7.55 [TAD at high nutrition]). The effect of stage of lactation was significant for $\mathrm{WBC}, \mathrm{RBC}$ and $\mathrm{Hb}$ values $(P<0.01)$. However, there were no stage of lactation by treatment interactions $(P>0.10)$. There was no effect of milking frequency or nutritional level, nor was there an interaction between the two main effects on neutrophil or lymphocyte counts $(P>0.10)$. Furthermore, the frequency of cows in each milking frequency and nutritional level treatment with counts of eosinophils and basophils that were greater than 0 did not differ $(P>0.10$, data not shown). However, a significantly higher frequency of $O A D$ cows had monocyte counts greater than 0 on the 7 and 28 July (80\%[16/20] v. $50 \%[10 / 20]$ and $50 \%[10 / 20]$ v. $20 \%[4 / 20]$ respectively, $P<0.05)$. There was a significant effect of stage of lactation of measurement on neutrophil and lymphocyte counts $(P<0.001)$. There also tended to be an interactive effect

Table 7 Effect of milking frequency (once or twice) on locomotion scores (Ismean) of cows at four sampling dates

\begin{tabular}{lccc}
\hline \hline & \multicolumn{2}{c}{ Milking frequency } & \\
\cline { 2 - 3 } Sample date & Once & Twice & s.e. \\
\hline 21 April & $10.48^{\mathrm{a}}$ & $8.35^{\mathrm{b}}$ & 0.225 \\
20 May & 8.41 & 7.52 & 0.225 \\
17 June & 6.90 & 7.03 & 0.225 \\
18 July & 7.22 & 6.83 & 0.225 \\
\hline \hline
\end{tabular}

${ }^{a, b}$ Values within rows with different superscripts are different $(P<0.001)$. between milking frequency and stage of lactation on lymphocyte counts $\left(F_{4,120}=2.38, P=0.055\right)$ (Table 9). OAD cows had lower lymphocyte counts on the 26 May than TAD cows. The interaction between milking frequency and stage of lactation was not significant for neutrophil counts $\left(F_{4,126}=1.53, P>0.10\right)$. Nevertheless, $O A D$ cows had numerically higher counts than TAD cows on 26 May (Table 9). Furthermore, the magnitude of the difference between the two milking frequency treatments was greatest on this date.

\section{Discussion}

The study presented here indicates that reducing the frequency of milking high yielding cows could have negative implications for their welfare, particularly at peak lactation. Cows milked once daily, especially those on high nutrition had increased milk leakage and higher udder firmness and locomotion scores. The composition of their blood was also altered relative to that of the TAD cows during peak lactation which could be indicative of immuno suppression.

Although not significant, it took longer to milk the OAD cows in the morning. This was probably a consequence of their higher milk yields at this time. Similarly, the high milk yield associated with the high nutritional level probably explains the increase in flow-rate compared with cows on a low nutritional level. Time to milk let down did not differ between milking treatments. This may be as a result of similar teat preparation.

In accordance with Gleeson et al. (2003) teat hyperkeratosis scores increased during the first 5 months of lactation and reduced in late lactation. Mein and Thompson (1993) suggested that higher yielding older cows tend to have

Table 8 Effect of milking frequency (once or twice) and nutritional level (high or low) on haematological parameters

\begin{tabular}{|c|c|c|c|c|c|}
\hline & \multicolumn{2}{|c|}{$\begin{array}{l}\text { Milking } \\
\text { frequency }\end{array}$} & \multicolumn{2}{|c|}{$\begin{array}{l}\text { Nutritional } \\
\text { level }\end{array}$} & \multirow[b]{2}{*}{ s.e. } \\
\hline & Twice & Once & High & Low & \\
\hline White blood cells $\left(\times 10^{9} / \mathrm{l}\right)$ & 6.98 & 7.51 & 7.51 & 6.97 & 0.226 \\
\hline Red blood cells ( $\left.\times 10^{12} / \mathrm{l}\right)$ & 6.18 & 6.34 & 6.28 & 6.24 & 0.130 \\
\hline Haemoglobin $(\mathrm{g} / \mathrm{dl})$ & $8.17^{\mathrm{a}}$ & $8.62^{b}$ & 8.44 & 8.35 & 0.129 \\
\hline Haematocrit (PCT) & 0.186 & 0.194 & 0.183 & 0.197 & 0.008 \\
\hline
\end{tabular}

\footnotetext{
${ }^{a, b}$ Values within rows with different superscripts are different $(P<0.05)$.
} 
Table 9 Effect of milking frequency (once or twice) on differential counts (least-square means) of neutrophils and lymphocytes at five sampling dates

\begin{tabular}{lccccc}
\hline \hline & \multicolumn{3}{c}{ Milking frequency } \\
\cline { 2 - 3 } \cline { 5 - 6 } Sample date & \multicolumn{2}{c}{ Once } & & \multicolumn{2}{c}{ Twice } \\
\cline { 2 - 3 } \cline { 5 - 6 } 4 May & 76.8 & 22.8 & & 76.3 & 23.4 \\
26 May & 68.1 & 27.9 & & 77.4 & 21.9 \\
16 June & 77.6 & 22.0 & & 76.5 & 22.6 \\
7 July & 57.3 & 36.3 & & 55.6 & 38.8 \\
28 July & 60.0 & 33.4 & & 56.9 & 36.4 \\
\hline \hline
\end{tabular}

Lymphocytes s.e. $=2.35$, Neutrophils s.e. $=2.08$.

more teat hyperkeratosis and therefore it could be expected that pluriparous cows would have a higher teat HK scores post calving than primiparous cows. The fact that pluriparous cows were used in this study could have masked differences in milking frequency for HK. Even though daily milking time was significantly longer for TAD cows, their teat condition was not adversely affected relative to the OAD cows. On the other hand, there was a positive correlation between milking time and teat hyperkeratosis for the cows milked once daily at high nutrition. This correlation was evident during the peak production period, when cows milked once daily at high nutrition had higher milk yields compared with the other treatments at the morning milking. Some individual cows milked once daily at high nutrition had milk yields in excess of $30 \mathrm{~kg} /$ day. It took $50 \mathrm{~s}$ and $45 \mathrm{~s}$ longer to milk these animals at the morning milking compared with cows milked once daily at low nutrition and TAD cows, respectively. This would suggest that prolonged cluster-on times at one milking might result in teats being more susceptible to HK. Thus, it is particularly important to ensure optimum milking unit performance when milking cows once per day. Optimum milking unit performance maybe defined as harvesting of milk in the shortest possible time without compromising on udder health or milk quality. Guidelines for quantifying the performance of milking units have been described (Mein, 1997).

Almost $30 \%$ of the cows milked once per day showed evidence of milk leakage. This was considerably higher than that reported $(5.5 \%)$ by Klass et al. (2005) when observations were made at a similar time point, just prior to milking. However, the mean milk yield per cow per milking reported in that study $(14.0 \mathrm{~kg})$ was considerably lower than the daily milk yield per cow $(O A D=21 \mathrm{~kg})$ recorded in the present study (O'Brien et al., 2005). The higher level of milk leakage in this study did not appear to affect the number of clinical cases of mastitis observed during this period (O'Brien et al., 2005).

The positive correlation shown between udder firmness and locomotion scores was similar to that shown by Boelling and Pollott (1998). That study concluded that a high locomotion score was primarily a problem in older cows with a large udder. In this study, the udder was distended owing to the large volume of milk produced by the cows during peak lactation. The findings indicate that the cows had some difficulty adopting normal locomotion as a result. Furthermore, there is some evidence from a parallel study of the hoof health of these cows that the abnormal locomotion adopted by the once daily milked cows resulted in higher heel erosion scores in these animals (L. Boyle et al., unpublished results).

Lymphocytes, macrophages, neutrophils and other cells associated with the immune response possess beta-adrenergic receptors on their surface membranes. Glucocorticoids affect the cells of the immune system in a number of ways. Under the influence of increased circulating concentrations of glucocorticoids, the relative and absolute populations of different classes of immune cells are altered. There is a reduction in the number of monocytes and lymphocytes, particularly T lymphocytes (Fauci and Dale, 1974; Dale et al., 1975; Fauci, 1975). Concurrently there is an increase in neutrophil population due to an expression of polymorphonuclear cells from bone marrow reserves (Dale et al., 1975). Indeed, the relationship between stress induced activation of the HPA axis and alteration of immune functions is well established (Anisman, 2002). In the present study although not affected overall, OAD cows had lower lymphocyte counts and higher neutrophil counts at the end of May. Considering that the other welfare indicators employed in this study suggest that the cows milked once daily and particularly those on a high nutritional level experienced some stress at this time, it is possible that this was responsible for the altered immune response seen in these animals. Nevertheless, in the absence of measurements of cortisol concentrations at this time our interpretation of these findings is somewhat speculative. In any case, the neutrophilia and lymphopenia observed in the present study were not of sufficient potential to pre-condition the immune system for further exposure to stress. However, the changes may have had immune suppression consequences (Radostits et al., 1994) and as such warrant further investigation.

In conclusion the increase in milk leakage, higher udder tension and locomotion scores in conjunction with changes in blood cells, suggests that OAD milking may have caused some discomfort to the cows during peak lactation. $A$ reduction in the concentrate input to $O A D$ cows during this period could ameliorate this problem.

\section{Acknowledgements}

The authors gratefully acknowledge the technical assistance of J.P. Murphy, J. Kenneally, T. Condon and general farm staff in the conduct of this study.

\section{References}

Anisman H 2002. Stress, immunity, cytokines and depression. Acta Neuropsychiatrica 14, 251-261.

Blake RW and McDaniel BT 1978. Relationship among rates of milk flow, machine time, udder conformation, and management aspects of milking efficiency. A review. Journal of Dairy Science 61, 363-378. 
Boelling D and Pollott GE 1998. Locomotion, lameness, hoof and leg traits in cattle. I Phenotypic influences and relationships. Livestock Production Science 54, 193-203.

Boyle L, O'Brien B and Gleeson D 2005. Effect of milking frequency and nutrition on cow behaviour and welfare. Proceedings of Irish Grassland Agricultural Research Forum. p. 51. Tullamore, Co Offaly, 14-15 March, 31.

Bruckmaier RM and Hilger M 2001. Milk ejection in dairy cows at different degrees of udder filling. Journal of Dairy Research 68, 369-376.

Dale DC, Fauci AS, DuPont Guerry IV and Wolff SM 1975. Comparison of agents producing a neutrophilic leukocytosis in man. Journal of Clinical Investigation 56, 808-813.

Davis SR, Farr VC and Stelwagen K 1999. Regulation of milk loss and milk composition during once-daily milking: a review. Livestock Production Science 59, 77-94.

Dunn JA 1989. Psychoneuroimmunology for the psychoneuroendocrinologist. A review of animal studies of nervous system-immune system interactions. Psychoneuroendocrinology 14, 251-274.

Elbers AR, Miltenburg $D$, Lange $D$ de, Crauwels AP, Barkema HW and Schukken YH 1998. Risk factors for clinical mastitis in a random sample of dairy herds from the southern part of the Netherlands. Journal of Dairy Science 81, 420-426.

Fauci AS 1975. Mechanism of corticosteroid action on lymphocyte subpopulations. I. Redistribution of circulating $\mathrm{T}$ and $\mathrm{B}$ lymphocytes to the bone marrow. Immunology 28, 669-679.

Fauci AS and Dale DC 1974. The effects of in vivo hydrocortisone on subpopulations of human lymphocytes. Journal of Clinical Investigation 53, 240-246.

Gleeson DE, O'Callaghan EJ and Rath M 2003. The effects of genotype, milking time and teat-end vacuum pattern on the severity of teat-end hyperkeratosis. Irish Journal of Agriculture and Food Research 42, 195-203.

Hamann J 1987. Effect of machine milking on teat condition: a literature review. International Dairy Federation (IDF) Bulletin No. 215, 33-53

Klass IC, Enevoldsen C, Ersboll AK and Tolle U 2005. Cow-Related Risk Factors for Milk Leakage. Journal of Dairy Science 88, 128-136.

Littell RC, Milliken GA, Stroup WW and Wolfinger RS 1996. SAS System for Mixed Models. SAS Institute Inc., Cary, NC.

Manson FJ and Leaver JD 1988. The influence of concentrate amount on locomotion and clinical lameness in dairy cattle. Animal Production 47, 185-190.

Mein GA 1997. Quantifying the performance of milking units. In Proceedings International Conference on Machine Milking and Mastitis. pp. 26-36. Teagasc, Cork, 23 May.

Mein GA and Thompson PD 1993. Milking the 30,000-pound herd. Journal of Dairy Science 76, 3294-3300.

Michel G, Seffner W and Schulz J 1974. The problem of hyperkeratosis of the teat duct epithelium in cattle. Monatsheft für Veterinärmedizin 29, 570-574.
Neijenhuis F 1998. Teat end callosity classification system. In Proceedings of the Fourth International Dairy Housing Conference, St Louis, Missouri, 28-30 January, pp. 117-123.

Neijenhuis F, Barkema HW, Hogeveen $\mathrm{H}$ and Noordhuizen JPTM 2000. Classification and longitudinal examination of callused teat-ends in dairy cows. Journal of Dairy Science 83, 2795-2804.

O'Brien B, Gleeson D and Mee JF 2005. Effect of milking frequency and feeding level on milk production, somatic cell count and reproductive performance of dairy cows over the first 20 weeks of lactation. Proceedings of Irish Grassland Agricultural Research Forum. Tullamore, Co Offaly, 14-15 March, 31, p. 28.

O'Brien B, Gleeson D and Berry DP 2006. Effect of milking frequency and nutritional level on lactation curve characteristics of spring-calving dairy cows. Proceedings of Irish Grassland Agricultural Research Forum, Tullamore, Co Offaly, 15-16 March, 32, p. 14.

O'Callaghan KA, Cripps PJ, Downham DY and Murray RD 2003. Subjective and objective assessment of pain and discomfort due to lameness in dairy cattle. Animal Welfare 12, 605-610.

Osterman S and Redbo I 2000. Effects of milking frequency on lying down and getting up behaviour in dairy cows. Applied Animal Behaviour Science 70, 167-176.

Persson Waller K, Westermark T, Ekman T and Svennerstyen-Sjaunja K 2003. Milk leakage - An increased risk in automatic milking systems. Journal of Dairy Science 86, 3488-3497.

Radostits OM, Blood DC and Gay CC 1994. Disease of the blood and bloodforming organs. In A textbook of the disease of cattle, sheep, pigs, goats and horses, 8th ed. Bailliere Tindall, W.B. Saunders \& Co, London, UK.

Rémond B, Aubailly SA, Chilliard Y, Dupont D, Pomiès D and Petit M 2002. Combined effects of once-daily milking and feeding level in the first three weeks of lactation on milk production and enzyme activities, and nutritional status, in Holstein cows. Animal Research 51, 101-117.

SAS Institute Inc. 1989. SAS/STAT User's guide. SAS Institute Inc., Cary, NC.

Schukken YH, Grommers FJ, van de Geer D, Erb HN and Brand A 1991. Risk factors for clinical mastitis in herds with low bulk milk somatic cell count. 2. Risk factors for Escherichia coli and Staphylococcus aureus. Journal of Dairy Science 74, 826-832.

Shearn MFH and Hillerton JE 1996. Hyperkeratosis of the teat duct orifice in dairy cows. Journal of Dairy Research 63, 525-532.

Sieber RL 1980. The relationship of bovine teat end lesions to mastitis and machine milking. Proceedings of the International Conference on Cattle Diseases, Tel Aviv, pp. 189-199.

Sieber RL and Farnsworth RJ 1981. Prevalence of chronic teat-end lesions and their relationship to intramammary infection in 22 herds of cattle. Journal of the American Veterinary Medical Association 178, 1263-1267.

Waage S, Odegaard SA, Lund A, Brattgjerd S and Rothe T 2001. Case-control study of risk factors for clinical mastitis in postpartum dairy heifers. Journal of Dairy Science 84, 392-399. 